\title{
Training of adolescent multipliers from the perspective of health promotion core competencies
}

Formação de adolescentes multiplicadores na perspectiva das competências da promoção da saúde Formación de adolescentes multiplicadores en la perspectiva de las competencias de la promoción de la salud

\section{Kely Vanessa Leite Gomes da Silva',", Gleice Adriana Araújo Gonçalves",I, Shayane Bezerra dos Santos", Maria de Fatima Antero Sousa Machado"', Cristiana Brasil de Almeida Rebouças", Viviane Martins da Silva", Lorena Barbosa Ximenes"}

' Universidade Regional do Cariri, Center for Biological and Health Sciences, Department of Nursing. Crato, Ceará, Brazil "Universidade Federal do Ceará, Department of Nursing, Postgraduate Program in Nursing. Fortaleza, Ceará, Brazil.

III Universidade Regional do Cariri, Center for Biological and Health Sciences, Postgraduate Program in Nursing and Master's in Family Health Professional. Crato, Ceará, Brazil.

How to cite this article:

Silva KVLG, Gonçalves GAA, Santos SB, Machado MFAS, Rebouças CBA, Silva VM, et al. Training of adolescent multipliers from the perspective of health promotion core competencies. Rev Bras Enferm [Internet]. 2018;71(1):89-96. DOI: http://dx.doi.org/10.1590/0034-7167-2016-0532

Submission: 02-04-2017 Approval: 04-09-2017

\section{ABSTRACT}

Objective: Recognize the domains of health promotion core competencies in the training process of adolescents carried out by nursing students. Method: Qualitative and descriptive study, which used the theoretical methodological contribution Developing Competencies and Professional Standards for Health Promotion Capacity Building in Europe (CompHP), carried out with 14 nursing students. Results: There were four domains: Enable Change; Mediate through Partnership; Communication; and Leadership. These domains came from the interest and commitment of adolescents in intersectoral partnership, the use of communication techniques, and the role of facilitator to catalyze learning and empowerment. Conclusion: There were some domains of core competency in the training of adolescents, suggesting that nursing students act as health promoters. Challenges for Nursing are the implementation of a theoretical contribution of CompHP in undergraduate and ongoing training to carry out health promotion action.

Descriptors: Nursing; Adolescent; Health Promotion; Core Competencies; Health Education.

\section{RESUMO}

Objetivo: Reconhecer os domínios das competências de promoção da saúde no processo formativo de adolescentes realizado por acadêmicos de Enfermagem. Método: Estudo qualitativo e descritivo, que utilizou o aporte teórico metodológico Developing Competencies and Professional Standards for Health Promotion Capacity Building in Europe (CompHP0), realizado com 14 acadêmicos de Enfermagem. Resultados: Evidenciaram-se quatro domínios: Mudança Ativa; Mediar através de Parceria; Comunicação; e Liderança. Esses domínios advieram do interesse e do compromisso dos adolescentes na parceria intersetorial, no uso de técnicas de comunicação e no papel de facilitador para catalisar o aprendizado e o empoderamento. Conclusão: Percebeuse que houve a presença de alguns domínios de competência na formação dos adolescentes, sugerindo que os acadêmicos de enfermagem atuassem como agentes promotores da saúde. Constituem-se desafios para a Enfermagem a implementação de aporte teórico do CompHP na graduação e formação permanente para efetivar ações no campo da promoção da saúde.

Descritores: Enfermagem; Adolescente; Promoção da saúde; Competências; Educação em Saúde.

\section{RESUMEN}

Objetivo: Reconocer los dominios de las competencias de promoción de la salud en el proceso formativo de adolescentes realizado por académicos de Enfermería. Método: Estudio cualitativo y descriptivo, que utilizó el aporte teórico metodológico DevelopingCompetenciesand Professional Standards for Health PromotionCapacityBuilding in Europe (CompHP0), realizado con 14 académicos de Enfermería. Resultados: De evidenciaron cuatro dominios: Cambio Activo; Mediar a través de Sociedad; 
Comunicación; y Liderazgo. Esos dominios adveraron del interés y del compromiso de los adolescentes en la sociedad intersectorial, en el uso de técnicas de comunicación y en el rol de facilitador para catalizar el aprendizaje y el empoderamiento. Conclusión: Se notó que hubo la presencia de algunos dominios de competencia en la formación de los adolescentes, sugiriendo que los académicos de enfermería actuasen como agentes promotores de la salud. Se constituyen desafíos para la Enfermería la implementación de aporte teórico del CompHP en la graduación y formación permanente para efectivar acciones en el campo de la promoción de la salud. Descriptores: Enfermería; Adolescente; Promoción de la Salud; Competencias; Educación en Salud.

\section{INTRODUCTION}

Adolescence is understood as the stage of life between childhood and adulthood, marked by rapid changes in growth and development brought about by psychobiological processes, as well as by transformations that result from interactions proper to the socioeconomic and political-cultural context, in which the subjects are inserted. In Brazil, among the approaches related to adolescent health, reproductive issues stand out, but there is a differential that expresses their vulnerability to the different forms of violence and the increasing incidence of mortality, evidenced especially by external causes, such as aggressions and road traffic accidents, among others ${ }^{(1)}$.

Vulnerability consists of factors of a biological, epidemiological, social and cultural nature and their interaction broadens or reduces the risk or protection of a person at the time of a particular disease, risk or trauma and replaces the classic concept of risk factors $^{(2)}$. In response, the challenge is to work with programs, laws, and policies that support a qualified approach.

Seeking to follow the principles of the Unified Health System (SUS), the Ministry of Health has expanded its borders in order to work with intersectoral policies. From this perspective, it created the Health in School Program (HSP), which is the fruit of an intersectoral health and education policy, instituted in 2007.

The HSP is a privileged space for health promotion and prevention of aggravations and diseases, contributing to the integral development and enabling the school community to confront the vulnerabilities that jeopardize the full development of Brazilian children, adolescents and young adults ${ }^{(3)}$.

In this sense, given the importance of the adolescent as a multiplier of knowledge, the methodology of peer education is used, which consists of a process of teaching and learning in which adolescents are prepared to take an active role in programs and activities with and for other adolescents and young people.

In this direction, the health and education secretariats of the municipality of Crato, Ceará State has established a partnership with nursing students who are members of the Adolescer com Saude [Adolescent with Health] extension project of the Regional University of Cariri - URCA.

This project was conceived in 2008 and works with educational practices in the school, which collaborate in the training of young people and in the formation of citizens who are aware and committed to the community's health problems. Activities include workshops on Sexuality and Affectivity, Sexual and Reproductive Health, Teenage Pregnancy, Sexually Transmitted Diseases (STDs), Alcohol, Drugs and Sport. These workshops are in the focus of the Public Policies for adolescents, from the perspective of health promotion and prevention through the adoption of a healthy lifestyle.

With regard to the training of adolescent multipliers, within the perspective of health promotion, it is intended that this process will be guided by core competencies. Competencies in the field of health promotion are defined as a composition of knowledge, skills and values that the individual must have for the development of tasks in a standardized manner ${ }^{(4)}$.

The theoretical framework, which bases the core competencies of health promotion to guide their actions, is presented with the document developed in 2012 by the European workshop of the International Union for Health Promotion and Education (UIPES), the project Developing Competencies and Professional Standards For Health Promotion Capacity Building in Europe (CompHP) aims to establish methods to implement standards in health promotion ${ }^{(5)}$.

At CompHP, competencies encompass values (equity, social justice, ethics, autonomy of individuals), skills (conceptual principles of health promotion) and knowledge, listed in 47 competencies and 9 domains. The domains are: (1) Enable Change; (2) Advocate for Health; (3) Mediate through Partnership; (4) Communication; (5) Leadership; (6) Assessment; (7) Planning; (8) Implementation; and (9) Evaluation and Research. Together, they provide a guide for the development of skills and competencies in health promotion to strengthen training and professional practice in Brazil ${ }^{(5)}$.

The present study allows reflections for the development and reorientation of health practices carried out in teaching, extension projects and assistance that enable effective programs to promote health, as well as the delegation of power for adolescents within their role as a multiplier, to act together with their peers.

\section{OBJECTIVE}

The study aimed to recognize the domains of competency in health promotion by the CompHP in the training process of adolescent multipliers of HSP performed by nursing students

\section{METHOD}

\section{Ethical aspects}

The study complied with the guidelines and regulatory norms of research involving human beings according to Resolution No. 466/12 of the National Health Council/Ministry of Health and was approved by the Research Ethics Committee. All participants signed the Free and Informed Consent Form, anonymity was guaranteed and the research entailed minimal risks to the participants, 
such as discomfort and or fatigue, besides promoting social relevance, with significant advantages for the study subjects.

\section{Theoretical-methodological framework}

Within the scope of competencies for health promotion, it is worth mentioning the historical framework regarding the first conceptual bases and policies for health promotion with a socio-environmental and inclusive approach, developed from the international conferences, notably the Conferences of Ottawa (Canada) In 1986, Adelaide (Australia) in 1988, Sundsvall (Sweden) in 1991 and Jakarta (Indonesia) in 1997. In Latin America, the IV International Conference on Health Promotion in Bogotá (Colombia) took place in 1992 and brought the theme to the Sub-regional context ${ }^{(6)}$. The main objective of these conferences was to reiterate the need to redirect public health programs, with a focus on combating situations of vulnerability related to diseases ${ }^{(7)}$.

At the Nairobi conference in 2006, discussions on the demands of society were recurrent. Authors point out that the current international scenario shows a growth of public policies in Health Promotion, making it necessary to develop professional competencies for the effective creation of programs and actions for this purpose. They also consider that for the strengthening of health promotion at a global level, it is important to prepare a group of trained professionals with the tools, skills and abilities to translate theory, policy and research into effective health promotion programs ${ }^{(8)}$.

Competency, therefore, can be defined as the combination of essential knowledge, skills and values necessary for the individual to perform tasks according to a standard ${ }^{(4)}$. Scholars point out the historical aspects for building health promotion skills, noting that a number of countries have participated in its construction, such as New Zealand, Scotland and Israel, as well as another group of countries such as Australia, Canada and Europe, which have contributed most energetically to this discussion ${ }^{(9)}$. Based on international meetings between these countries, there is a need to create a theoretical framework of health promotion core competencies common to all countries and to guide health promotion practices. Thus, at the Galway Conference in 2008, the eight domains of competency ${ }^{(10-11)}$ were presented.

In addition to this reference, a document developed by the European workshop of the International Union for Health Promotion and Education (UIPES), has highlighted the project Developing Competencies and Professional Standards for Health Promotion Capacity Building in Europe (CompHP) $)^{(5)}$. This project began in 2009 and has as its main objective the formation of a consensus in which methods for the implementation of standards in health promotion are established, aiming at innovation and best health practices in Europe ${ }^{(9)}$.

In CompHP, domains provide a guide to the development of skills and competencies in health promotion ${ }^{(9)}$, which provide a useful basis for training and practice scenarios, as well as for academic preparation and continuing professional development. A health promoter must demonstrate competency and skill acquisition that addresses all domains presented in CompHP(4-5).

\section{Type of study}

A descriptive study with a qualitative approach was carried out with Nursing students, members of the Adolescent with Health extension project of the Regional University of Cariri (URCA), in the municipality of Crato - Ceará, which developed the training of adolescents.

\section{Methodological procedures}

In order to carry out the process of training of adolescent multipliers in schools, the following steps were taken: I - Training of nursing students by municipal management with emphasis on the design of the HSP, as well as on the themes to be addressed with the adolescents; II - Organization of the Adolescent with Health extension project in the sense of distributing the students for the work to be developed in the schools; III - Implementation of workshops in schools with adolescents. In this way, the nursing students, members of the Adolescent with Health extension project, participated in the study, soon after completing the steps described above.

Participants were identified by the interview order number, which made it possible to organize and preserve anonymity (A1, A2, A3, etc.). The semi-structured interview was used as a data collection instrument, since it presented aspects such as the perception of the student about their preparation for training the adolescents and also data on the interaction established with the adolescents during the workshops.

\section{Study scenario}

The study was carried out at the Regional University of Cariri - URCA, with 14 undergraduate Nursing students, members of the Adolescent with Health Extension Group. Among these members, 12 were female and two were male, aged 20 to 24 years. Students were in the 6th to 9th grades. The Adolescent with Health extension project works with workshops carried out by nursing students, using participatory methodologies appropriate to the adolescent public attending public schools in the municipality.

\section{Data collection and organization}

The interviews took place at scheduled times, from September to October 2015, according to the availability of the participants, in a reserved space, individually and respecting their privacy. It should be noted that each interview lasted on average 20 minutes. The statements were the basis for elaborating the analytical categories of the study, as characterized by the domains of CompHP.

\section{Data analysis}

Analysis of the study was based on the competencies referenced by CompHP(6) and other studies that enabled the reflections mentioned here. The analyzed data are presented in categories according to the domains found in the conduction of the formative process of multiplier adolescents.

\section{RESULTS}

Next, the categories composed by the CompHP domains will be presented and these will enable reflections on the 
process of training of multiplier adolescents of the HSP , carried out by nursing students, with a view to promoting health. From the statements of the study participants, the following domains can be seen: Enable Change; Mediate through Partnership; Communication; and Leadership. These domains of competency for health promotion are considered below:

\section{Enable Change}

The "Enable Change" domain was configured through the participation of adolescents in the training process carried out by the students. The following statements indicate the results of adolescents active in the training process expressed in participation.

They [adolescents] were very attentive and participative, understood what we wanted to give them and proved that they had the capacity and understanding to pass the work forward. This was perceived by their interest in involvement and participation. (A. 1)

The dialog demonstrates the presence of participation and interest among the adolescents, characterizing the presence of the Enable Change domain. This domain is evident in the provision for learning with a view to promoting health, as noted in the statement:

The adolescents were extremely interested, since they asked questioned, clarified their concerns and participated in the dynamics. (A. 6)

\section{Mediate through Partnership}

The "Mediate through Partnership" domain was present in the dialogs about how the training of nursing students took place to qualify them for the training of adolescents. It should be emphasized that the training offered to the students by the Health and Education Departments of the municipality, through a partnership between the project Adolescent with Health of the university and the municipality of Crato-CE, reinforces the existence of a cooperation, which configures The CompHP domain "Mediate through Partnership":

There was initially training by the Health and Education Secretariat of Crato regarding this method of empowerment, which is education among peers. (A. 4)

The presence was observed of said domain in the training of the students in the following report, in which the disposition and commitment with the actions of health promotion were evidenced, founded on common interests between the actors involved:

We were invited to participate in a training program that the Crato Health Department provided for the Adolescent with Health group, in order to enable us and facilitate the actions of the HSP [Health in School Program]. (A. 3)

\section{Communication}

We observed the students were identifying with their role as facilitators in the teaching-learning process and as such, the
CompHP domain of Communication was demonstrated in the following statements:

[...] We always had the students' feedback with us, they participated in an active way. (A. 2)

I was a facilitator of the knowledge of the topics that we approached that day, I see that my role was really a facilitator, that is, to help in this process of teaching and learning. (A. 7)

The CompHP domain of Communication was also evidenced in a context in which the activities carried out contributed to a greater participation of the adolescents, as well as to the use of culturally appropriate techniques to specific groups, the adolescents in this case, which was seen in the following statement:

They [adolescents] proved themselves capable of the $d y$ namics and the discussions that were proposed, the group was very constructive, because they often started certain debates, so it was very dynamic. (A. 8)

Participatory communication between academics and adolescents was perceived in the following report:

As I worked on the topic of sexuality, it is a theme that every student likes very much to approach this theme, so they liked it very much, wanted to participate in all the dynamics, totally open, active [sic], had doubts, actively participated. (A. 14)

\section{Leadership}

This domain was evidenced in the formative process of the adolescents through the facilitating action of the academics for the learning and consequent multiplication of the knowledge with other adolescents.

I was empowering the students so they could empower their colleagues. My role was to be a facilitator of knowledge for them. (A. 10)

[...] so the meeting served as a roadmap for them to develop their actions in school with other teenagers. (A. 11)

[...]We exchange experiences, wisdom, knowledge, build and make a critical reflection of certain situations and awaken the spirit of facilitator in the students. (A. 13)

It can also be inferred that the Nursing student acted as mediator of the teaching-learning process, which contributed to the autonomy and the decision by disseminating the knowledge among their peers.

The "Leadership" domain permeating the work of the health promoting agent was reflected in the following statements:

I think I was a facilitator in this context of providing information for them to continue the work that they experienced. (A. 9)

I was empowering the students so they could empower their colleagues. My role was to be knowledge facilitator for them. (A. 12) 


\section{DISCUSSION}

The Enable Change domain consisted of activating individuals, groups, communities and organizations to build capacity for health promotion action to improve health and reduce related inequalities ${ }^{(5)}$.

This domain was evidenced in the process of the adolescents acting in the workshops offered by the nursing students. It is perceived that youth participation is a complex process and that the experiences and knowledge learned are resources to develop autonomy and the social actor his or herself ${ }^{(12)}$. Thus, it can be said that participation is a process that promotes learning, which is capable of becoming an autonomous process and of providing empowerment for decision making.

In this sense, it is underscored that the process of training teenage multipliers points to the presence of the "Enable Change" domain. It is observed that the elements identified in the process, present in the categories of the study, confirm that these adolescents can, in their individual reality, perform knowledge multiplication actions with their peers in order to consider health promotion actions from the context in which they live.

As for the domain "Mediate through Partnership", its importance was observed in the cooperation between nursing students and the health and education departments for the development of actions in the HSP. This is a program that proposes to be a new design of health education policy, which envisages health and education in an integral way and part of a broad training for citizenship and full enjoyment of the human rights of children, adolescents and young people ${ }^{(3)}$.

This domain implies working collaboratively across disciplines, sectors and partners to increase the impact and sustainability of health promotion action, seeking to involve partners on an inter-sectorial basis to contribute to collaborative work, mediating between different sectoral interests ${ }^{(5)}$.

A similar study on the conduct of education and health for adolescents about the use of alcohol and other drugs recommends that the nurse, as a health promoter, collaborates with professionals working with adolescents in the school environment, seeking strategies for intervention in an appropriate and satisfactory manner ${ }^{(13)}$.

Thus, the inter-sectoral relationship established in this study was successful, from the perspective of achieving collaborative work, in order to influence the development of public policies that positively impact health, i.e. in this case working in the $\mathrm{HSP}^{(5)}$.

In this way, it is envisaged that intersectoral action constitutes a process of learning and resolving by the actors involved and that integrated action responds to the problems of the population of a defined territory, moving from the limit of necessity to that of freedom ${ }^{(14)}$.

Regarding the definition of roles and responsibilities in the planning and execution of the HSP, there are three concepts that must be improved and problematized in school health: participation; and an inter-sectoral and interdisciplinary approach ${ }^{(15)}$.

The domain "Communication" was identified in the reports on the formation of adolescents as multipliers of knowledge, evidencing the use of culturally appropriate techniques for this specific group. The dialogs of the students have highlighted the role of facilitator in the teaching-learning process, as well as the reports on the use of communication to favor the participation of adolescents in the workshops developed.

This domain implies communication for health promotion action in an effective way, using techniques and technologies appropriate for different publics; and using effective communication skills, including verbal or non-verbal texts and listening skills ${ }^{(5)}$.

It is noticed in the processes of training with adolescents that there is a need to value that which the group contributes to the subject, so that they can express their questions, their needs and their experiences, thereby building a partnership to exchange concepts with the facilitators, expanding and replicating the knowledge presented ${ }^{(16)}$.

Learning takes place when there is a re-elaboration or even a deconstruction of knowledge from the information that is presented to the subjects. Thus, there is a construction of knowledge founded on cognitive parameters, motivational aspects, reflection and critical thinking faced with information that is constantly being updated ${ }^{(17)}$.

Nursing students use the term "facilitator", whose role is to encourage reflections, since the focus is on the participants' activities in a group. To develop and facilitate a group activity, the facilitator needs some requirements, which can be highlighted: training, personal skills with the theme; to work, knowledge and skills of how to work in a group, some procedures and practical experience ${ }^{(18)}$.

Still in the field of "Communication", it was observed its purpose for participation, and the latter as a premise for carrying out the activities developed in the workshops.

From the perspective of participation, a study on approach in education and health with young people emphasizes that youth participation in activities, programs and services enables a better understanding of the dimension of learning associated with cognitive reflexivity, as mediation for the autonomy and authorship of the subject ${ }^{(12)}$.

In a study in which workshops were held with adolescents with teaching-learning techniques, the authors defended the adoption of educational practices with a dialogical character, capable of promoting the active participation of this public, with the intention of making them protagonists, responsible for their health and improving their quality of life $\mathrm{e}^{(19)}$.

The present study contradicts the findings of a study that investigated the understanding of production conditions of nurses' discourse in the practice of health education with adolescents, in which it was pointed to a traditional lineage in which political and socio-cultural subjects are deprived of their spaces and realities and the educator stands as the holder of true knowledge to the detriment of the adolescent's subjectivity ${ }^{(20)}$.

Given the above, it can be said that the participation generated by the "Communication" domain is a process that promotes learning, which is capable of becoming autonomous and of providing empowerment for decision making. Thus, it is believed, in this study that the participation of the adolescents during the training process to become multipliers occurred in the light of the Project of competencies for health promotion, pointing to the presence of the "Communication" domain of CompHP. 
Regarding the domain "Leadership", it was observed that the academics are mediators for learning and consequent empowerment of the adolescents. The "Leadership" domain requires values from the health promoter that contribute to the development of a shared vision and strategic direction for health promotion actions.

This domain implies the use of leadership skills that facilitate empowerment and participation, including teamwork, negotiation, motivation, conflict resolving, decision making, facilitation and problem solving ${ }^{(5)}$.

As to the training of nurses, a study states that, even though the emphasis given to the concept of leadership by the New Curriculum Guidelines, as a professional competency of nurses, we can see the scant use of Leadership Theories in the studies reviewed, which could contribute to the little instrumentalization of the nurses in that which concerns the application of leadership in health services.

It should be emphasized that leadership can help overcome fragmented and embedded behaviors that are experienced in different health scenarios, by encouraging new action proposals based on dialogue and evidence-based practices, which tend to have positive repercussions in the quality of care provided ${ }^{(21)}$.

With regard to the role of leader in the incorporation of new knowledge, the idea is defended that the multiplier has the function of removing the veil from the eyes of the learners and of making them understand the meaning of the new knowledge to be acquired, the new skills to be developed and the attitudes to be assumed ${ }^{(22)}$.

Still on the exercise of leadership it is evident that the students worked with the objective of incorporating new knowledge to improve the practice and respond to the emerging challenges in health promotion, or that is, to provide knowledge so that the adolescents are trained and become multipliers of this knowledge among their peers.

In a study about the use of motivation as a work tool for nurses in the practice of health education in primary care, it was inferred that motivation enhances the health education actions by stimulating the self-care of users of health services and institutions, making it possible to expand their autonomy and participation in health promotion. It is underscored that the motivation inserted as a work tool in the health education proposal, strengthens the daily actions of nurses, providing empowerment to use new ways to plan, organize and evaluate their work ${ }^{(23)}$.

In this study, it is inferred that students recognized their role in the training process as facilitators of the actions developed, thus identifying the domain of Leadership among the core competencies for health promotion in the process of training teenage multipliers.

The present study is consistent with the findings of an integrative review on facilitating aspects of the teaching-learning process in nurses' training, in which it was shown that teacherstudent interaction stands out as the main facilitative factor, which is highlighted by most of the selected articles ${ }^{(24)}$.

As for the role of the facilitator, it is perceived that the role of the facilitator is taken into account by the students and it is pointed out that the health promotion actions carried out in the workshops were aimed at making adolescents empowered and able to replicate acquired knowledge.
The present study is in line with the integrative review on the configuration of core competencies for health promotion in the training of nurses, since it was observed that the students of the last graduation periods appeared to have a more appropriate view of the role of the nurse for health promotion, suggesting that maturity and experience contribute to the development of these core competencies by students ${ }^{(25)}$.

\section{Study limitations}

A limitation of this study was the need to approach the phenomenon studied from the perspective of the adolescents about the training process during the workshops, although the focus of this study is the nursing students. The inclusion of adolescent multipliers could reveal other perspectives not apprehended by students as trainers. It should be noted that the results reflect a particular context, which requires caution and evaluations to transfer interpretations to other regions and institutions.

Therefore, further research, with different designs and approaches, is necessary to explore the application of core competency domains with undergraduate nursing students, in order to understand how health and education services interact in these partnerships.

\section{Contributions to Nursing, health and public policy}

This research contributes to nursing, health and public policies in order to ratify the importance of using the CompHP areas of core competency by the Nursing professional, in order to result in more effective action and behavior in the field of health promotion that aim to improve the living conditions of the adolescent population, surpassing the notion of resolving problems and diseases.

The importance emerges for the elaboration of public policies that recommend the appropriation of these domains by the health professionals with a focus on the improvement of adolescent health care and quality of life.

\section{FINAL CONSIDERATIONS}

The nursing students' dialogs pointed to the presence of the following domains of $\mathrm{CompH}$ health promotion competencies: Enable Change; Mediate through Partnership; Communication; and Leadership. The presence of these domains in the formative process of adolescents indicates: a new form of health practice, which goes beyond the traditional hegemonic medical model; and shows that the nursing students acted as health promoters.

We identified the absence of the following CompHP domains: Advocate for Health, Assessment, Planning, Implementation, and Evaluation and Research, considered relevant to determine the scope, impact and effectiveness of health promotion action. This implies a weakness in the process of developing core competencies for academics to act as health promoters.

It should be emphasized that the training processes that ensure the domains of core competencies can result in more effective action in the field of health promotion and improved quality of life. Thus, it is inferred that nursing students who participate in training experiences contemplating CompHP 
domains of core competency, such as the one described in this study, have a differential as health promotion agents, insofar as it gives them the possibility of future nursing practice that encompasses health promotion action for individuals, family and community.

The challenge is underscored for Nursing to recognize and implement the theoretical contribution of the CompHP domains in undergraduate courses and in the permanent formation of these professionals, which would result in more effective action in the field of health promotion.

\section{ACKNOWLEDGEMENTS}

Logistical and financial support for carrying out the present research offered by the Fundação Cearense de Apoio ao Desenvolvimento Científico e Tecnológico (FUNCAP).

\section{REFERENCES}

1. Brasil. Ministério da Saúde. Secretaria de Atenção em Saúde. Departamento de Ações Programáticas Estratégicas. Diretrizes nacionais para a atenção integral à saúde de adolescentes e jovens na promoção, proteção e recuperação da saúde. Brasília (DF): Ministério da Saúde [Internet]. 2010 [cited 2016 Jul 22]. Available from: http://www.pucsp.br/ecopolitica/downloads/docs _oficiais/1_D_2010_ Diretrizes nacionais atencao integral saude adolescentes.pdf

2. Vilela WV, Doreto DT. Sobre a experiência sexual dos jovens. Cad Saúde Pública [Internet]. 2006 [cited 2016 Jun 12];22(11):246772. Available from: http://www.scielo.br/pdf/csp/v22n11/21.pdf

3. Brasil. Ministério da Saúde. Departamento de Atenção Básica. Programa Saúde na Escola (PSE).Brasília (DF): Ministério da Saúde [Internet]. 2012 [cited 2016 Jun 15]. Available from: http://dab.saude.gov.br/portaldab/pse.php

4. Dempsey C, Barry MM, Battel-kirk B. Literature review: developing competencies for health promotion deliverable 3B. Galway: National University of Ireland [Internet]. 2010 [cited 2016 Jun 20]; Project number 20081209. Available from: https://aran.library. nuigalway.ie/bitstream/handle/10379/4442/CompHP_Literature_Review_Part_1.pdf?sequence = 1\&isAllowed =y

5. Dempsey C, Barry MM, Battel-kirk B. The CompHP core competencies framework for health promotion handbook: workpackage 4. Galway: Executive Agency for Health [Internet]. 2011 [cited 2016 May 29]; Project number 20081209. Available from: http:// www.iuhpe.org/images/PROJECTS/ACCREDITATION/CompHP_LiteratureReviewPart1.pdf

6. Buss PM. Promoção da saúde e qualidade de vida. Ciênc Saúde Colet[Internet]. 2000 [cited 2016 Aug 01];5(1):163-77. Available from: http://www.scielo.br/pdf/csc/v5n1/7087.pdf

7. Mendes IAC. Development and health: the declaration of Alma-Ata and posterior movements. Rev Latino-am Enfermagem [Internet]. 2004 [cited 2016 Jun 20];12(3):447-8. Available from: http://www.scielo.br/pdf/rlae/v12n3/en_v12n3a01.pdf

8. Battel-kirk B, Barry MM, Taub A, Lysoby L. A review of the international literature on health promotion competencies: identifying frameworks and core competencies. Global Health Promotion, London [Internet]. 2009 [cited 2016 Jul 08];16(2):12-20. Available from: https://aran.library.nuigalway.ie/handle/10379/2283

9. Pinheiro DGM, Scabar TG, Maeda ST, Francolli LA, Pelicioni MCF, Chiesa AM. Competências em promoção da saúde: desafios da formação. Saúde Soc [Internet]. 2015 [cited 2016 Aug 15];24(1):180-8. Available from: http://www.scielo.br/pdf/sausoc/v24n1/01041290-sausoc-24-1-0180.pdf

10. Allegrante JP, Barry MM, Auld ME, Lamarre MC, Taub A. Toward international collaboration on credentialing in health promotion and health education: the Galway Consensus Conference. Health Educ Behav[Internet]. 2009 [cited 2016 May 12];36(3):427-438. Available from: https:// aran.library.nuigalway.ie/bitstream/handle/10379/2785/02\%202009_ja_credentialing_in_hp_heb_36.pdf?sequence $=1 \& i s A l l o w e d=y$

11. Barry MM, Allegrante JP, Lamarre MC, Auld ME, Taub A.The Galway Consensus Conference: international collaboration on the development of core competencies for health promotion and health education. Glob Health Prom[Internet]. 2009 [cited 2016 Jul 09];16(2):5-11. Available from: https://www.aran.library.nuigalway.ie/bitstream/handle/10379/2281/2009 ja_galway_consensus_ ghp_162.pdf? sequence $=1 \&$ isAllowed $=y$

12. Guimarães JS, Lima IMSO. Participação juvenil e promoção da saúde: estratégia de desenvolvimento humano. J Human Growth Develop [Internet]. 2011 [cited 2016 Jul 21];21(3):859-66. Available from: http:// www.pepsic.bvsalud.org/pdf/rbcdh/v21n3/12.pdf

13. Pedrosa SC, Costa DVS, Citó COM, Luna IT, Pinheiro PNC. Educação em saúde com adolescentes acerca do uso de álcool e outras drogas. Rev Enferm Cent O Min[Internet]. 2015[cited 2016 Aug 01];5(1):1535-41. Available from: http:// www.seer.ufsj.edu.br/ index.php/recom/article/view/402/843

14. Ferreira IRC, Vosgerau DSAR, Moysés SJ, Moysés ST. Diplomas Normativos do Programa Saúde na Escola: análise de conteúdo associada à ferramenta ATLAS TI. Ciênc Saúde Colet[Internet]. 2012[cited 2016 Jul 08];17(12):3385-98. Available from: http:// www.scielo.br/pdf/csc/v17n12/23.pdf

15. Casemiro JP, Fonseca ABC, Secco FVM. Promover saúde na escola: reflexões a partir de uma revisão sobre saúde escolar na América Latina. Ciênc Saúde Colet[Internet]. 2014 [cited 2016 Jul 24];19(3):829-40. Available from: http:// http://www.scielo.br/ $\mathrm{pdf} / \mathrm{csc} / \mathrm{v} 19 \mathrm{n} 3 / 1413-8123-\mathrm{csc}-19-03-00829 . \mathrm{pdf}$

16. Silveira RE, Reis NA, Santos AS, Borges MR. Workshops with teachers: health education for management with adolescents. Acta 
Paul Enferm [Internet]. 2012[cited 2016 Jul 04];25(2):169-74. Available from: http://www.scielo.br/pdf/ape/v25nspe2/27.pdf

17. Coutinho C, Lisboa E. Sociedade da informação, do conhecimento e da aprendizagem: desafios para educação no século XXI. Rev Educ [Internet]. 2011 [cited 2016 Aug 02];18(1):5-22. Available from: http://repositorium.sdum.uminho.pt/bitstream/1822/14854/1/ Revista_Educa \%C3\%A7\%C3\%A3o,VolXVIII,n\%C2\%BA1_5-22.pdf

18. Soares DP, Thielen IP. Projeto Transformando o Trânsito e a Perspectiva do Facilitador. Psicol: Ciênc Prof[Internet]. 2012[cited 2016 Aug 05];32(3):730-74. Available from: http://www.scielo.br/pdf/pcp/v32n3/v32n3a16.pdf

19. Almeida JRS, Oliveira NC, Moura ERF, Sabóia VPA, Mota MV, Pinho LGM. Oficinas de Promoção de saúde com adolescentes: relato de experiência. Rev Rene [Internet]. 2011 [cited 2016 Jun 05];12(n. esp.):1052-8. Available from: http://www.redalyc.org/ pdf/3240/324027978022.pdf

20. Coelho MMF, Miranda KCL, Gomes AMT, Silveira LC. Conditions of discourse production by nurses in educational practice with adolescents. Rev Enferm UERJ [Internet]. 2015 [cited 2016 Jul 13];23(1):9-14. Available from: http://www.facenf.uerj.br/v23n1/ v23n1a02.pdf

21. Amestoy SC, Backes VMS, Trindade LL, Canever BP. The scientific production regarding leadership in the context of nursing. Rev Esc Enferm USP [Internet]. 2012 [cited 2016 Jun 20];46(1):227-33. Available from: http://www.scielo.br/pdf/reeusp/v46n1/ en_v46n1a30.pdf

22. Caires JC. Competências e formação de gestores multiplicadores. In: VII Convibra Administração - Congresso Virtual Brasileiro de Administração [Internet]. 2013 [cited 2016 May 14]. Available from: http://www.convibra.com.br/upload/paper/adm/adm_1115.pdf

23. Silva KL, Araújo FL, Santos FBO, Andrade AM, Basílio NC, Sena RR. O que vem se falando por aí em competências no ensino da promoção da saúde na formação do enfermeiro? ABCS Health Sci. [Internet]. 2015 [cited 2016 Jul 05];40(3):286-93. Available from: http://files.bvs.br/upload/S/2318-4965/2016/v40n3/a5360.pdf

24. Chicharo SCR, Florêncio MV, Alves SZSP, Cortez EA, Andrade M, Valente GSC. Factors facilitating the teaching-learning in nursing education: an integrative review. Rev Pesqui. Cuid Fundam [Internet]. 2016 [cited 2016 Aug 23];8(2):4099-108. Available from: http://www.seer.unirio.br/index.php/cuidadofundamental/article/view/3408/pdf_1841

25. Weykamp JM, Cecagno D, Hermel PP, Tolfo FD, Siqueira HCH. Motivação: ferramenta de trabalho do enfermeiro na prática da educação em saúde na atenção básica. Rev Bras Cienc Saúde [Internet]. 2015 [cited 2016 Aug 08];19(1):5-10. Available from: http://periodicos.ufpb.br/index.php/rbcs/article/view/25215/15033 